\title{
Citron, a Rho-Target, Interacts with PSD-95/SAP-90 at Glutamatergic Synapses in the Thalamus
}

\author{
Tomoyuki Furuyashiki, ${ }^{1}$ Kazuko Fujisawa, ${ }^{1}$ Akiko Fujita, ${ }^{1}$ Pascal Madaule, ${ }^{1}$ Shigeo Uchino, ${ }^{2}$ \\ Masayoshi Mishina, ${ }^{3}$ Haruhiko Bito, ${ }^{1}$ and Shuh Narumiya ${ }^{1}$ \\ ${ }^{1}$ Department of Pharmacology, Kyoto University Faculty of Medicine, Sakyo-ku, Kyoto 606-8315, Japan, ${ }^{2}$ Yokohama \\ Research Center, Mitsubishi Chemical Corporation, Aoba-ku, Yokohama 227-8502, Japan, and ${ }^{3}$ Department of Molecular \\ Neurobiology and Pharmacology, University of Tokyo Graduate School of Medicine, Bunkyo-ku, \\ Tokyo 113-0033, Japan
}

Proteins of the membrane-associated guanylate kinase family play an important role in the anchoring and clustering of neurotransmitter receptors in the postsynaptic density (PSD) at many central synapses. However, relatively little is known about how these multifunctional scaffold proteins might provide a privileged site for activity- and cell type-dependent specification of the postsynaptic signaling machinery. Rho signaling pathway has classically been implicated in mechanisms of axonal outgrowth, dendrogenesis, and cell migration during neural development, but its contribution remains unclear at the synapses in the mature CNS. Here, we present evidence that Citron, a Rho-effector in the brain, is enriched in the PSD fraction and interacts with PSD-95/synapse-associated protein
(SAP)-90 both in vivo and in vitro. Citron colocalization with PSD-95 occurred, not exclusively but certainly, at glutamatergic synapses in a limited set of neurons, such as the thalamic excitatory neurons; Citron expression, however, could not be detected in the principal neurons of the hippocampus and the cerebellum in the adult mouse brain. In a heterologous system, Citron was shown to form a heteromeric complex not only with PSD-95 but also with NMDA receptors. Thus, Citron-PSD-95/ SAP-90 interaction may provide a region- and cell type-specific link between the Rho signaling cascade and the synaptic NMDA receptor complex.

Key words: Citron; thalamus; PSD-95; synapse; Rho; NMDA receptor
Rho family proteins are small GTPases that act as molecular switches in various cellular processes critical for the regulation of cell morphology and cell polarity (Nobes and Hall, 1995; Narumiya, 1996). A large part of their biological effects are mediated through regulation and reorganization of the actin cytoskeleton via a concerted action of numerous molecular targets for various Rho family members: Rho, Rac, and CDC42 (for review, see Lim et al., 1996; Narumiya et al., 1997; Hall, 1998). In most species, ranging from Caenorhabditis elegans, Aplysia, and Drosophila melanogaster to mammals, Rho family proteins are expressed in the CNS (Madaule and Axel, 1985; Chen and Lim, 1994; Malosio et al., 1997; Olenik et al., 1997; Sasamura et al., 1997). Genetic mutations of some key players of the Rho signaling pathway have been associated with a severe defect in neuronal migration (Zipkin et al., 1997; Steven et al., 1998), axon guidance (Luo et al., 1994), and dendritic outgrowth (Luo et al., 1996), which also led

Received June 8, 1998; revised Oct. 9, 1998; accepted Oct. 15, 1998.

This work was supported by Grants-in-Aid from the Ministry of Education, Science, Sports, and Culture (S.N. and H.B.), a Kyoto University Academic Research Promotion Award (H.B.), and grants from the Asahi Glass Foundation, the Fujiwara Foundation, the Japan Brain Foundation, the Tanabe Frontier Medical Conference, and the Yamanouchi Foundation for Research on Metabolic Disorders (to H.B.). T.F. and K.F. are recipients of a predoctoral and a postdoctoral fellowship, respectively, from the Japanese Society for the Promotion of Science. We thank T. Ishizaki, N. Watanabe, M. Eda, and Y. Shiraishi for helpful discussion; Y. Hata and Y. Takai for various PDZ yeast two-hybrid constructs; Y.P. Hsueh and M. Sheng for a PSD-95 expression vector; R. Shigemoto and H. Oida for invaluable advice on in situ hybridization; S. Kikumura for performing some immunostaining experiments; A. Mizutani for advice on PSD fractionation; K. Nonomura for technical assistance; and T. Arai and H. Nose for secretarial help.

Correspondence should be addressed to Shuh Narumiya, Department of Pharmacology, Kyoto University Faculty of Medicine, Yoshida-Konoe, Sakyo-ku, Kyoto 606-8315, Japan.

Copyright (C) 1998 Society for Neuroscience $\quad 0270-6474 / 98 / 190109-10 \$ 05.00 / 0$ to major behavioral anomalies. Various studies in in vitro systems confirmed a major role for Rho GTPases in regulating neuronal morphology (Nishiki et al., 1990; Jalink et al., 1994; Mackay et al., 1995; Tigyi et al., 1996; Gebbink et al., 1997; Jin and Strittmatter, 1997; Kozma et al., 1997; Threadgill et al., 1997; Hirose et al., 1998). Furthermore, some loss-of-function mutations in several Rho GTPase signaling constituents (such as oligophrenin-1 or p21-activated kinase 3) were linked only with a mild cognitive impairment (primary mental retardation), without signs of other distinctive clinical features (Allen et al., 1998; Billuart et al., 1998). Such a wide spectrum of observed phenotypes is consistent with multiple neuronal roles for Rho GTPases and their effectors.

In this study, we identified a novel molecular interaction between Citron, a neuronal Rho-target (Madaule et al., 1995), and postsynaptic density (PSD)-95/synapse-associated protein (SAP)90, a member of the membrane-associated guanylate kinase (MAGUK) protein family (Cho et al., 1992; Kistner et al., 1993). Much attention has been focused recently on a postsynaptic protein complex in which PSD-95/Discs large/ZO-1 (PDZ) motif-containing MAGUK proteins, such as PSD-95/SAP-90, SAP-97/Dlg, SAP-102, or Chapsyn-110/PSD-93, may act as a scaffold for various neurotransmitter receptors, ion channels, or other signaling molecules (Woods and Bryant, 1993; Lahey et al., 1994; Kim et al., 1995, 1996; Kornau et al., 1995; Brenman et al., 1996; Cohen et al., 1996; Gomperts, 1996; Lau et al., 1996; Horio et al., 1997; Irie et al., 1997; Kennedy, 1997; Sheng and Wyszynski, 1997; Ziff, 1997). Our experiments indicate that Citron, a Rho-target molecule, is an intrinsic component of this PSD-95 protein complex in the PSD at certain, but not all, excitatory synapses in the forebrain. Citron, PSD-95, and NMDA receptor 
subunits were shown not only to colocalize at synapses but also to form a stable protein complex. Our results highlight the possibility that the Rho family proteins may participate in certain stages of NMDA receptor regulation via PSD-95, perhaps along with or during neuronal morphogenesis, dendritic outgrowth, synapse formation, and activity-dependent reorganization of the postsynaptic signaling machinery.

A complementary study, "Citron Binds to PSD-95 at Glutamatergic Synapses on Inhibitory Neurons in the Hippocampus," by Zhang et al. appears in this issue on pages 96-108.

\section{MATERIALS AND METHODS}

Cell culture and immunocytochemistry. Culture and maintenance of COS-7 cells was as described previously (Ishizaki et al., 1997). The production, culture, and maintenance of a stable transfectant Chinese hamster ovary $(\mathrm{CHO})$ line expressing heat-inducible alleles of mouse

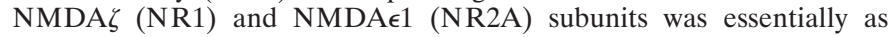
described previously (Uchino et al., 1997). The culture of mouse primary neurons was based on Bito et al. (1996) as modified from Wendland et al. (1994), using specific pathogen free-grade ICR mouse brains as starting material. Briefly, desired areas (thalamus or cerebral cortex) of the postnatal day 1 (P1)-P2 brain were carefully dissected and chopped into small slices in an ice-cold $20 \%$ fetal calf serum (FCS)-containing $\mathrm{Mg}^{2+}-/$ $\mathrm{Ca}^{2+}$-free HANKS [HANKS(-)] solution in a sterilized hood. After rinsing three times in cold HANKS(-) solution by decantation, the tissue was trypsinized $(10 \mathrm{mg} / \mathrm{ml}$; Sigma, St. Louis, MO) for $5 \mathrm{~min}$ at room temperature in $2 \mathrm{ml}$ of digestion solution (Wendland et al., 1994) in the presence of DNase (Sigma). After suction of the supernatant, the reaction was stopped with $10 \mathrm{ml}$ of $20 \%$ FCS-HANKS(-). After three rounds of rinse in cold HANKS(-) solution, the tissue was finally triturated in $2 \mathrm{ml}$ of dissociation solution HANKS(-)- $\mathrm{Mg}^{2+}(12 \mathrm{mM})$ using fire-polished Pasteur pipettes in the presence of DNase. The reaction was stopped by adding $3 \mathrm{ml}$ of $20 \%$ FCS-HANKS(-). After centrifugation, the pellet was collected and seeded at various densities onto a Matrigel (Becton Dickinson, Franklin Lakes, NJ)-coated glass coverslip.

Immunocytochemistry was performed as described by Wendland et al. (1994) and Bito et al. (1996), using neurons cultured for 8-11 d in vitro. Rabbit polyclonal antibodies were as follows: anti-GluR1 [1:300, Upstate Biotechnology (UBI), Lake Placid, NY]; and anti-Citron (1:1000) (Madaule et al., 1998). A goat polyclonal anti-Citron antibody (1:50; S-20; Santa Cruz Biotechnology, Santa Cruz, CA) was used for colocalization experiments (see Fig. 2); a qualitatively similar dendritic punctate staining pattern was seen using either anti-Citron antibody. Mouse monoclonal antibodies were as follows: anti-synaptophysin (1:400; clone SV P-38; Sigma); anti-PSD-95 (1:25-1:50; clone 6G6-1C9; Affinity Bioreagents, Golden, CO); anti-glutamic acid decarboxylase (GAD) (1:500; Chemicon; Temecula, CA); and anti-NR1 (1:200; clone 54.1; PharMingen, San Diego, CA). Either a set of goat anti-rabbit and anti-mouse secondary antibodies or a set of donkey anti-rabbit, anti-goat, and antimouse secondary antibodies, each conjugated with adequate fluorophores (FITC, Texas Red, or Cy5; Jackson ImmunoResearch, West Grove, PA), was used. Samples were observed using either an Axiophot epifluorescence microscope (Zeiss, Tokyo, Japan) with a $40 \times$ Apoplan (NA 1.4) objective or an MRC1024 laser scanning confocal microscope (Bio-Rad, Hercules, CA) equipped with a Zeiss Axiovert 100TV and a $63 \times$ Apoplan (NA 1.35) objective. Confocal images were acquired, analyzed, and processed using LaserSharp Version 2.1A (Bio-Rad). Figures $2 B$ and $6 C$ show images obtained as single confocal optical sections, and an illustration in pseudocolor was made with Photoshop 3.0 (Adobe Systems, San Jose, CA). The laser power, gain, and iris diaphragm were initially set such that the bleeding between separate emission wavelengths was kept at a negligible level.

In situ hybridization. Brain cryosections were obtained from 2-monthold mice and processed for in situ hybridization as described previously (Oida et al., 1995). An ${ }^{35}$ S-labeled antisense riboprobe was obtained using a $1.8 \mathrm{~kb}$ fragment of Citron coiled-coil region as a template (Madaule et al., 1995). Similar distribution was seen also using a digoxigenin-labeled probe (Roche Molecular Biochemicals, Indianapolis, IN) (data not shown).

Isolation of PSD fraction. PSD fraction was prepared essentially as described previously (Carlin et al., 1980), with minor modifications. Briefly, adult mouse whole brains were homogenized in buffer A $[0.32 \mathrm{M}$ sucrose, 5 mM HEPES-KOH, pH 7.4, 1 mm $\beta$-mercaptoethanol ( $\beta$-ME), and 2 mM EDTA] containing a cocktail of protease inhibitors (Complete Tablet; Roche Molecular Biochemicals) and centrifuged at $800 \times g$ for 10 min to recover the supernatant S1 and the pellet P1. S1 fraction was subjected to a centrifugation at $7,100 \times g$ for $15 \mathrm{~min}$ to obtain the pellet P2 and the supernatant S2. S2 was ultracentrifuged to separate the cytosolic fraction S3 and the crude microsomal fraction P3. P2 was resuspended in buffer $\mathrm{A}$ and again subjected to centrifugation at 8,200 $\times$ $g$ for $15 \mathrm{~min}$ to recover the synaptosomal fraction $\mathrm{P} 2^{\prime}$. P2' fraction was treated with an osmotic shock by diluting with double-distilled water and further centrifuged at $25,000 \times g$ for $20 \mathrm{~min}$ to generate the pellet LP1 and the supernatant LS1. The synaptic vesicle fraction LP2 was obtained as the ultracentrifugation pellet of LS1. LP1 was resuspended in buffer B (0.16 m sucrose, 5 mm Tris-HCl, pH 8.0, 0.5\% Triton X-100, $0.5 \mathrm{~mm}$ $\beta$-ME, 1 mM EDTA, and protease inhibitors), incubated at $4^{\circ} \mathrm{C}$ for 15 $\mathrm{min}$, and centrifuged at $33,000 \times \mathrm{g}$ for $20 \mathrm{~min}$. The pellet LP1P was resuspended and loaded onto a discontinuous sucrose gradient composed of $1.0 \mathrm{M}, 1.5 \mathrm{M}$, and $2.0 \mathrm{M}$ sucrose. After ultracentrifugation at $208,000 \times$ $g$ for $2 \mathrm{hr}$, the PSD fraction was recovered at the interface between 1.5 and $2.0 \mathrm{M}$ sucrose. PSD fraction was finally resuspended in $5 \mathrm{vol}$ of buffer C (0.16 m sucrose, 5 mm Tris-HCl, pH 8.0, 0.5\% Triton X-100, 75 mM $\mathrm{KCl}$, and $1 \mathrm{~mm}$ EDTA) and centrifuged at $208,000 \times g$ for $30 \mathrm{~min}$, and the recovered pellet, resuspended in buffer $\mathrm{A}$, was considered as the purified PSD fraction. Protein concentrations were measured using $\mathrm{Mi}$ cro BCA kit (Pierce, Rockford, IL) and a DC protein assay kit (Bio-Rad). One microgram of proteins of each fraction was loaded in each lane for a subsequent Western blot analysis (see Fig. $2 A$ ).

Transfection, immunoprecipitation, and immunoblot analysis. For immunoprecipitation experiments, $2 \times 10^{5} \mathrm{COS}-7$ cells were plated onto 60 $\mathrm{mm}$ dishes and $18 \mathrm{hr}$ later were transfected with $1 \mu \mathrm{g}$ each of GW1 PSD-95 (a gift from Y. P. Hsueh and M. Sheng, Harvard University, Boston, MA) and pCAG-Myc-CitronN (Madaule et al., 1998) using Lipofectamine Plus (Life Technologies, Gaithersburg, MD) according to the manufacturer's protocol. Twenty-four hours later, cells were scraped with a rubber policeman and lysed in a lysis solution $(50 \mathrm{~mm}$ Tris- $\mathrm{HCl}$, $\mathrm{pH} 7.4,150 \mathrm{~mm} \mathrm{NaCl}, 1 \% \mathrm{NP}-40$, and $0.5 \%$ sodium deoxycholate) containing a cocktail of protease inhibitors (Complete Tablet). Transfection into $\mathrm{CHO}$ cells were performed similarly, with minor modifications: cells were kept in the same original medium designed for this stable cell line (Uchino et al., 1997) throughout the transfection procedure, and heat-induction at $43^{\circ} \mathrm{C}$ in a $5 \% \mathrm{CO}_{2}$ humidified incubator was started $7 \mathrm{hr}$ before lysis and continued for $2 \mathrm{hr}$, followed by incubation at $37^{\circ} \mathrm{C}$ for another $5 \mathrm{hr}$.

For immunoblot analyses of mouse brain homogenates (see Figs. 1, 5), several brain areas were microdissected under the microscope in a cold room at $4^{\circ} \mathrm{C}$, and lysates were obtained using a buffer solution $(50 \mathrm{~mm}$ Tris- $\mathrm{HCl}, \mathrm{pH} 7.4$, and $150 \mathrm{~mm} \mathrm{NaCl}$ ) containing various kinds of detergent mixtures as indicated. Solubilization in an SDS-based homogenization buffer was performed as described previously (Lau et al., 1996). Five micrograms of proteins were loaded on each lane, unless stated otherwise.

After electrophoresis, the proteins were transferred onto an Immobilon polyvinylidene difluoride membrane (Millipore, Bedford, MA), and immunoreactive proteins were detected using ECL-Plus (Amersham Pharmacia Biotech, Piscataway, NJ) with the following concentration of primary antibodies: anti-Myc monoclonal (1:300; 9E10); rabbit antiCitron polyclonal (1:2000) (Madaule et al., 1998); anti PSD-95 monoclonal (1:2000; 6G6-1C9); and anti-NR2A/B polyclonal (1:200; Chemicon). In a preliminary series of experiments, several anti-PSD-95 monoclonal antibodies [clones 6G6-1C9 and 7E3-1B8 (1:2000; Affinity Bioreagents); clone K28/58.8.5 (1:2000; UBI)] were tested for immunological specificity and immunoprecipitation potency (see Fig. $1 D$ ). Each experiment was repeated several times, and a representative blot is shown.

Immunoprecipitation from COS-7 or CHO cell lysates was performed at room temperature using the ImmunoCatcher method (Cytosignal, Irvine, CA) following the manufacturer's instructions. Briefly, $200 \mu \mathrm{l}$ of lysates with $50 \mu \mathrm{g}$ of proteins were precleared using $10 \mu \mathrm{l}$ of Protein A/G resin preadsorbed with control rabbit serum or mouse IgG. Subsequently, antibodies $[10 \mu \mathrm{l}$ of anti-Myc polyclonal (Santa Cruz Biotechnology) and $2 \mu \mathrm{l}$ of anti-PSD-95 monoclonal (clone 6G6-1C9)] were added. Incubation with the antibody was performed at room temperature for $1 \mathrm{hr}$ using a rocking table, followed by a further incubation with $10 \mu \mathrm{l}$ of Protein $\mathrm{A} / \mathrm{G}$ resin for another $30 \mathrm{~min}$. Immunoprecipitation from thalamic lysates was performed similarly, except that $400 \mu \mathrm{g}$ of proteins were precleared, incubated for $2 \mathrm{hr}$ at $4^{\circ} \mathrm{C}$ with antibodies alone $[2-5 \mu \mathrm{l}$ of an 
A

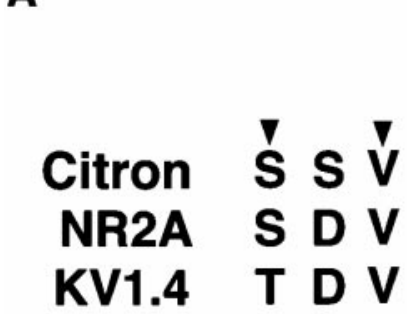

B

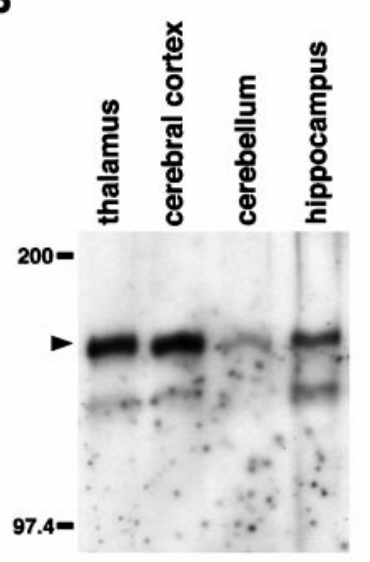

$\mathbf{E}$
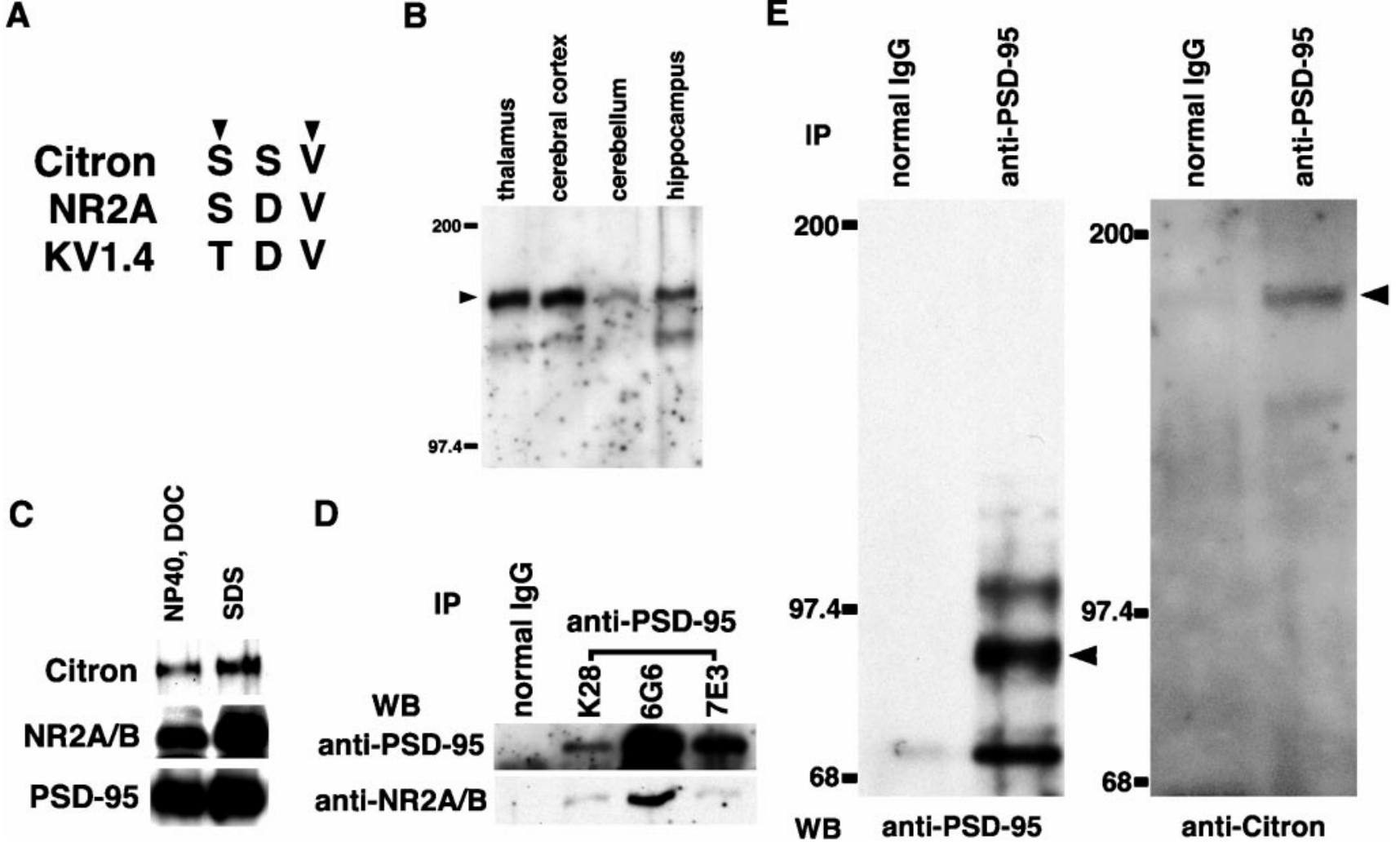

Figure 1. Identification of a Citron-PSD-95 complex in thalamic tissues. $A$, Presence of a consensus PDZ-binding tSXV motif at the C terminus of Citron. Alignment with the conventional tSXV motif in NR2A and Kv1.4. B, Western blot analysis of Citron expression in various mouse brain areas. Five micrograms of proteins were loaded in each lane. $C$, Examination of detergent solubility of Citron and several PSD-enriched proteins, including NR2A/B and PSD-95. D, Examination of the potency of three distinct anti-PSD-95 monoclonal antibodies to immunoprecipitate PSD-95 and PSD-95-associated proteins. Note the superiority of one clone, 6G6-1C9 (6G6), over the other two monoclonals [7E3-1B8 (7E3) and K28/58.8.5 (K28)] under our conditions. $E$, Identification of Citron in a PSD-95 immune complex prepared from thalamic lysates with the 6G6 monoclonal anti-PSD-95 antibody.

anti-PSD-95 monoclonal (clone 6G6-1C9); $20 \mu \mathrm{l}$ of the other antiPSD-95 monoclonals (clones 7E3-1B8 and K28/58.8.5); and $10 \mu \mathrm{l}$ of an anti-NR1 monoclonal (clone 54.1)] and then for another $8 \mathrm{hr}$ at $4^{\circ} \mathrm{C}$ in the presence of $10 \mu \mathrm{l}$ of Protein $\mathrm{A} / \mathrm{G}$ resin. Bound proteins were separated from the free proteins using a spin column, washed twice with $500 \mu \mathrm{l}$ of lysis buffer, and then solubilized in $50 \mu \mathrm{l}$ of Laemmli's SDS-PAGE buffer. Ten microliters of the sample were typically loaded onto a 5\% SDS-PAGE gel for further Western blot analyses. Despite the fact that the clone $6 \mathrm{G} 6-1 \mathrm{C} 9$ recognized the same protein bands as two other completely distinct anti-PSD-95 monoclonal antibodies (clones 7E3-1B8 and K28/58.8.5) in a Western blot from total brain lysates (data not shown), 6G6-1C9 showed far superior immunoprecipitation capacity (see Fig. 1D). Protein assay was performed using a Micro BCA kit (Pierce), with albumin as a protein standard.

Yeast two-hybrid assay. The yeast two-hybrid assay was performed as described previously (Madaule et al., 1995; Fujisawa et al., 1998). The C-terminal 73 amino acids of Citron was introduced by PCR into pBTM116 as pBTM-CitronCFull [or $\mathrm{C}(\mathrm{t} / \mathrm{SXV}+)$ ]. Another vector, pBTM-CitronC $\Delta$ [or $\mathrm{C}(\mathrm{t} / \mathrm{SXV}-)$ ], lacking the $\mathrm{C}$-terminal four amino acids of Citron in pBTM-CitronCFull, was similarly constructed. pVP16 PSD-95-2 containing all three PDZ motifs of PSD-95 (PDZ1+2+3) [kindly provided by Y. Hata (Takai BioTimer Project, ERATO, Japan Science and Technology Corporation) and Y. Takai (Osaka University, Suita, Japan)] was used as a bait.

\section{RESULTS}

\section{Identification of a possible Citron-PSD-95 complex}

A $180 \mathrm{kDa}$ protein Citron has recently been identified as a Rhotarget enriched in the brain (Madaule et al., 1995). Citron preferentially binds the GTP-bound form of RhoA (Madaule et al., 1995; Fujisawa et al., 1998), suggesting that Citron may be a neuronal effector molecule for the GTPase switch Rho (Narumiya, 1996; Hall, 1998). A detailed analysis of the primary sequence of Citron cDNA indicated the presence of a consensus terminal SXV $(\mathrm{tSXV})$ motif in its C-terminal end (Fig. 1A). We reasoned that this motif may constitute a privileged site for protein-protein interaction with PDZ domain-containing proteins, such as PSD95/SAP-90 and its related proteins (Kennedy, 1997; Songyang et al., 1997). If this were the case, Citron might be a component of the PSD-95-associated signaling complex. To test such a possibility, we first set out to examine the presence of Citron in a PSD-95 immune complex. A Western blot analysis in the adult mouse brain provided evidence for a strongest expression of Citron in the thalamus and cerebral cortex; expression level was far less prominent in the cerebellum and hippocampus (Fig. $1 B$; see also Fig. $3 A$ ). We then asked if Citron immunoreactivity (IR) could be coprecipitated as part of a PSD-95 complex in the thalamus. In our hands, a buffer containing a $1 \%$ NP-40-0.5\% sodium deoxycholate (DOC) mixture was able to solubilize detectable amounts of PSD-95, as well as NMDA receptor subunits $\mathrm{NR} 1$ and $\mathrm{NR} 2 \mathrm{~A} / \mathrm{B}$, although to a slightly lesser extent than in the presence of $2 \%$ SDS (Fig. 1C). Furthermore, NR2A/B subunits could be coimmunoprecipitated with PSD-95 using both an anti-PSD-95, as well as an anti-NR1, antibody (Fig. 1D; data not shown). Thus, we used a $1 \%$ NP-40$0.5 \%$ DOC detergent mixture as a standard solubilization detergent in all subsequent analyses. We also found that the monoclonal anti-PSD-95 antibody 6G6-1C9 was particularly suitable for coim- 
munoprecipitation under these conditions (Fig. 1D). As shown in Figure $1 E$, this anti-PSD-95 antibody was able to immunoprecipitate not only PSD-95 and related proteins but also a $180 \mathrm{kDa}$ Citron from detergent-solubilized thalamic lysates; control mouse IgG was unable to immunoprecipitate either one. This finding raised the possibility of Citron being present, at least in part, within the PSD-95 protein complex in neurons.

We next examined the subcellular localization of Citron protein in the neurons using a biochemical fractionation method. As shown in Figure $2 A$, Citron protein was highly enriched in the PSD fraction, along with NR1 subunit and PSD-95. Together, these data suggested the possibility that Citron and PSD-95 may coexist and interact with each other in the PSD. Immunofluorescent staining of thalamic neuronal cultures was attempted to further investigate a possible colocalization between Citron and PSD-95. A significant proportion of IR was distributed at puncta nearly apposed to those of synaptophysin (Fig. $2 B, a-c$ ) at the GAD-negative, presumably excitatory, synapses (data not shown). A substantial overlap was observed between Citron-IR and NR1-IR, primarily on dendrites and spines (Fig. 2B, $d-f$ ). Citron colocalized with PSD-95 in a sizable proportion of puncta (Fig. 2B, g-i), although evidently not all Citron puncta were PSD-95-positive and not all PSD-95 puncta contained Citron-IR. Citron-IR was substantially inhibited when the Citron antibody was preadsorbed with an excess amount of the epitope peptide, without altering the IR of a second antibody used in combination (data not shown). Similar distribution and colocalization of Citron-IR were observed also in cultured cortical neurons (data not shown). Together, these data support the idea that a significant portion of Citron protein in forebrain neurons may be involved in forming a complex with the anchoring protein PSD-95 in the PSD at certain glutamatergic synapses.

\section{Area-specific and developmentally regulated expression of Citron in the brain}

As a way to explore the significance of such an interaction, we next determined the locus of high-level Citron expression within the brain by in situ hybridization. As illustrated in Figure $3 A-C$, a predominant expression of Citron mRNA was demonstrated in the adult thalamus. A dense amount of silver grains was detected in neuronal cell bodies in most of the subareas containing thalamic excitatory neurons (Fig. $3 B, C$; data not shown), confirming our immunocytochemical data. Thus, Citron expression may not be ubiquitous within the CNS but localized to certain brain areas or cell types.

To further confirm this point, a detailed examination was attempted in other brain areas as well. A moderate and general mRNA expression was detectable in the cerebral cortex and the subiculum of the hippocampal region (Fig. 4A-D). However, the principal glutamatergic neurons of the hippocampus, represented by the CA1-CA3 pyramidal neurons and the dentate granule neurons, were devoid of a significant amount of Citron mRNA (Fig. $4 E, F)$. Only a minor and scattered subset of hippocampal neurons, reminiscent of the distribution of inhibitory interneurons, exhibited a high amount of silver grains (Fig. 4E,F). A restricted expression pattern was also observed in the cerebellum in which the molecular, Purkinje cell, and granule cell layers were absent in silver deposits (Fig. 4G); however, a subpopulation of deep cerebellar nuclei expressed a high amount of Citron mRNA (Fig. 4H). Consistent with our results, another group found specific expression of Citron protein at glutamatergic synapses of hippocampal inhibitory neurons (Zhang et al., 1999).
Because brain Rho activity has been classically associated with early neural development (Malosio et al., 1997; Threadgill et al., 1997), we examined the developmental expression profile of Citron in several mouse brain areas (Fig. 5). To our surprise, in a P1 brain, a significant Citron expression was detectable only in the cerebellum. In other areas, such as thalamus, cerebral cortex, or hippocampus, Citron expression parallelled that of other synaptic proteins, such as $\alpha$-CaMKII (Erondu and Kennedy, 1985) or PSD-95 itself (Cho et al., 1992; Kistner et al., 1993) and gradually increased until P14. A transient expression of a larger splice variant of Citron (Fig. 5, asterisk) at $\sim 200 \mathrm{kDa}$ was detected between P3 and P7, again only in the cerebellum (Fig. 5). This is noteworthy, because this period coincides with the critical time window when cerebellar granule neurons divide and migrate to start forming reliable parallel fiber-Purkinje neuron connections. In another work, the larger form of Citron (Citron-K) was shown to contain an $\mathrm{N}$-terminal kinase domain and was critical for the regulation of cytokinetic division of the cytoplasmic content in dividing cells (Madaule et al., 1998).

\section{A Citron-PSD-95-NMDA receptor complex}

The data presented so far indicated that Citron, at least in part, colocalized and associated with PSD-95 in situ. Citron thus may be a component of a postsynaptic signaling complex containing PSD-95 and related proteins, especially in the context of thalamic glutamatergic synapses. To gain further insight into the nature of Citron-PSD-95 interaction, we overexpressed both Citron and PSD-95 in a heterologous system and examined the direct binding between the two proteins. When a Myc-tagged Citron and a full-length PSD-95 were expressed in COS-7 cells, both an antiMyc and an anti-PSD-95 antibody could immunoprecipitate either one of the two proteins (Fig. 6A), strongly supporting our previous finding obtained in detergent-solubilized thalamic lysates (Fig. 1E). To formally demonstrate a direct interaction between the two proteins, we then examined whether the C-terminal tSXV of Citron was required to directly interact with the PDZ domains of PSD-95 using a yeast two-hybrid system. When a bait containing all three PDZ domains of PSD-95 (PDZ1+2+3) was used, an intact Citron C-terminus $[\mathrm{C}(\mathrm{t} / \mathrm{SXV}+)]$ was able to generate a significant amount of lacZ activity, whereas a deletion mutant lacking the final four amino acids QSSV of Citron [C(t/SX V-)] was unable to induce lacZ at all (Fig. 6B). Thus, Citron was bound presumably directly to the PDZ domains of PSD-95 via its C terminus.

One possible role for Citron binding to PSD-95 is that the localization of Citron may be regulated by PSD-95. In COS-7 cells overexpressing Myc-Citron, however, the localization of the Myc epitope was unchanged with or without coexpression of PSD-95 (data not shown). In contrast, PSD-95, which was expressed diffusely in the cytoplasm and to some extent at the cytoplasmic membrane when expressed alone, was redistributed (Fig. 6C) to a yet uncharacterized vesicular compartment, a preferred locus for Citron expression in many dividing cells (Madaule et al., 1998). A Citron mutant lacking the Rho-binding domain was shown to distribute diffusely (Madaule et al., 1998). Together, these data indicate that Citron localization might influence the distribution of PSD-95, at least within the context of COS-7 cells.

We finally asked whether a Citron-PSD-95 complex was still competent for binding to other PSD-95-binding proteins. A physiologically important candidate for PSD-95 binding at thalamic excitatory synapses is NR2A, because the C-terminal end of NR2A subunit possesses a prototypical tSXV motif (Fig. 6C) and 
A
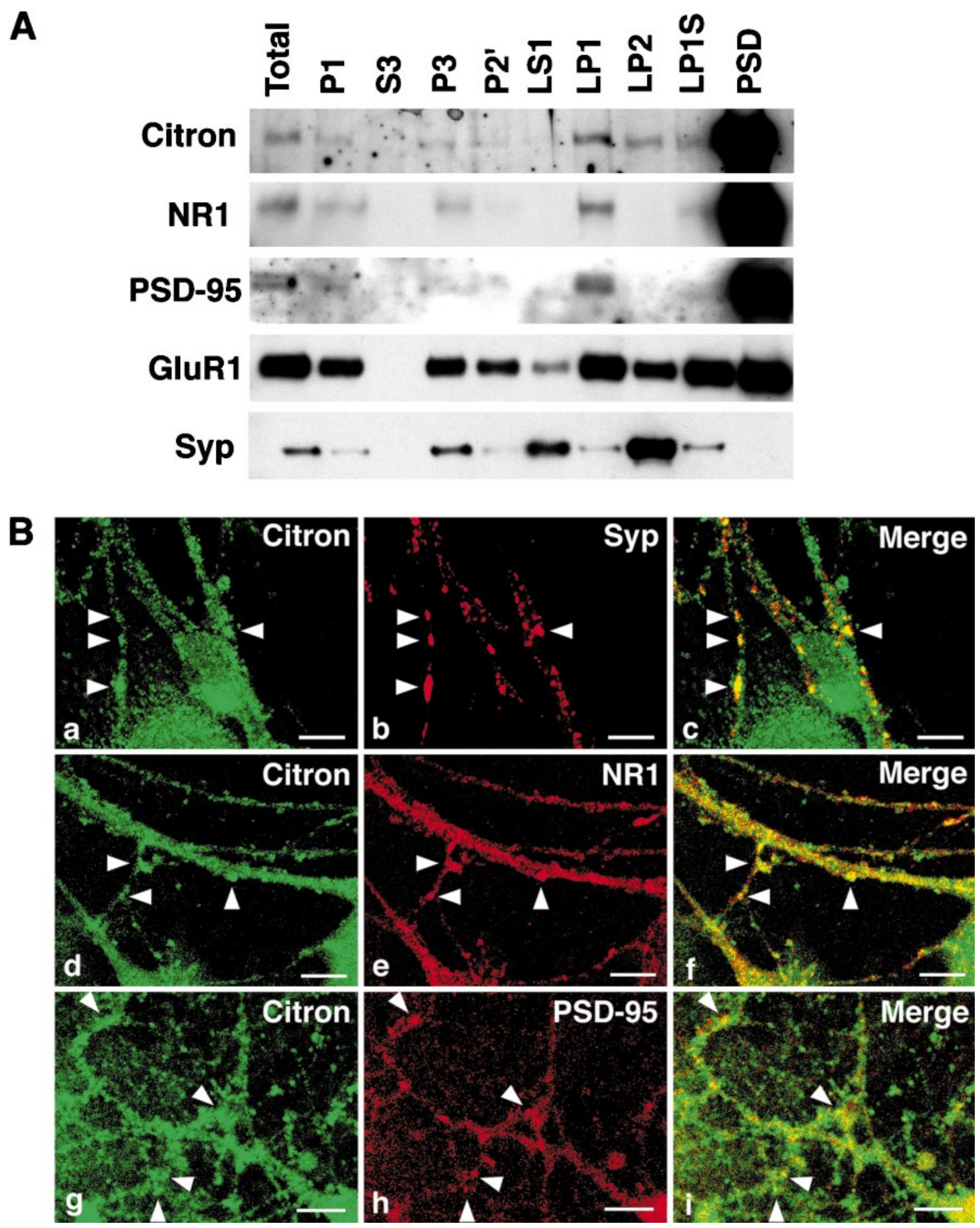

Figure 2. Citron and PSD-95 cofractionate into the PSD fraction and are colocalized at thalamic glutamatergic synapses. $A$, Biochemical fractionation (See Materials and Methods for the definition of each fraction) reveals that Citron is highly enriched into the PSD fraction, along with NR1 and PSD-95. A similar amount $(1 \mu \mathrm{g})$ of proteins was loaded in each lane. Citron is detected in the total homogenate (Total) and P1 fraction (P1) but not in the cytosolic fraction (S3). Citron is expressed in most membrane fractions but is more concentrated in the synaptic membrane fraction $(L P 1)$ than in the microsomal membranes $(P 3)$. Although slightly detected in the synaptic vesicle fraction $(L P 2)$, a predominant amount of Citron is found in the PSD fraction (PSD). $B, a-c$, Colocalization between Citron and synaptophysin, a presynaptic vesicle marker; $d-f$, colocalization between Citron and NR1; $g-i$, colocalization between Citron and PSD-95. Typical puncta showing a colocalization are illustrated by arrowheads. Note that the Citron puncta only partially overlap with the synaptophysin (Syp)-, NR1-, or PSD-95-positive puncta. Occasionally, a spinehead-like structure was visualized using anti-Citron antibodies. Scale bars, $10 \mu \mathrm{m}$.

has been shown to bind preferentially to the second PDZ motif and to a lesser extent to the first PDZ motif of PSD-95 (Kim et al., 1995; Kornau et al., 1995). We took advantage of a CHO stable expressant (Uchino et al., 1997) in which both the NR1 and NR2A subunits of the NMDA receptor could be co-induced by use of heat shock (Fig. 7A). After Citron and PSD-95 expression 

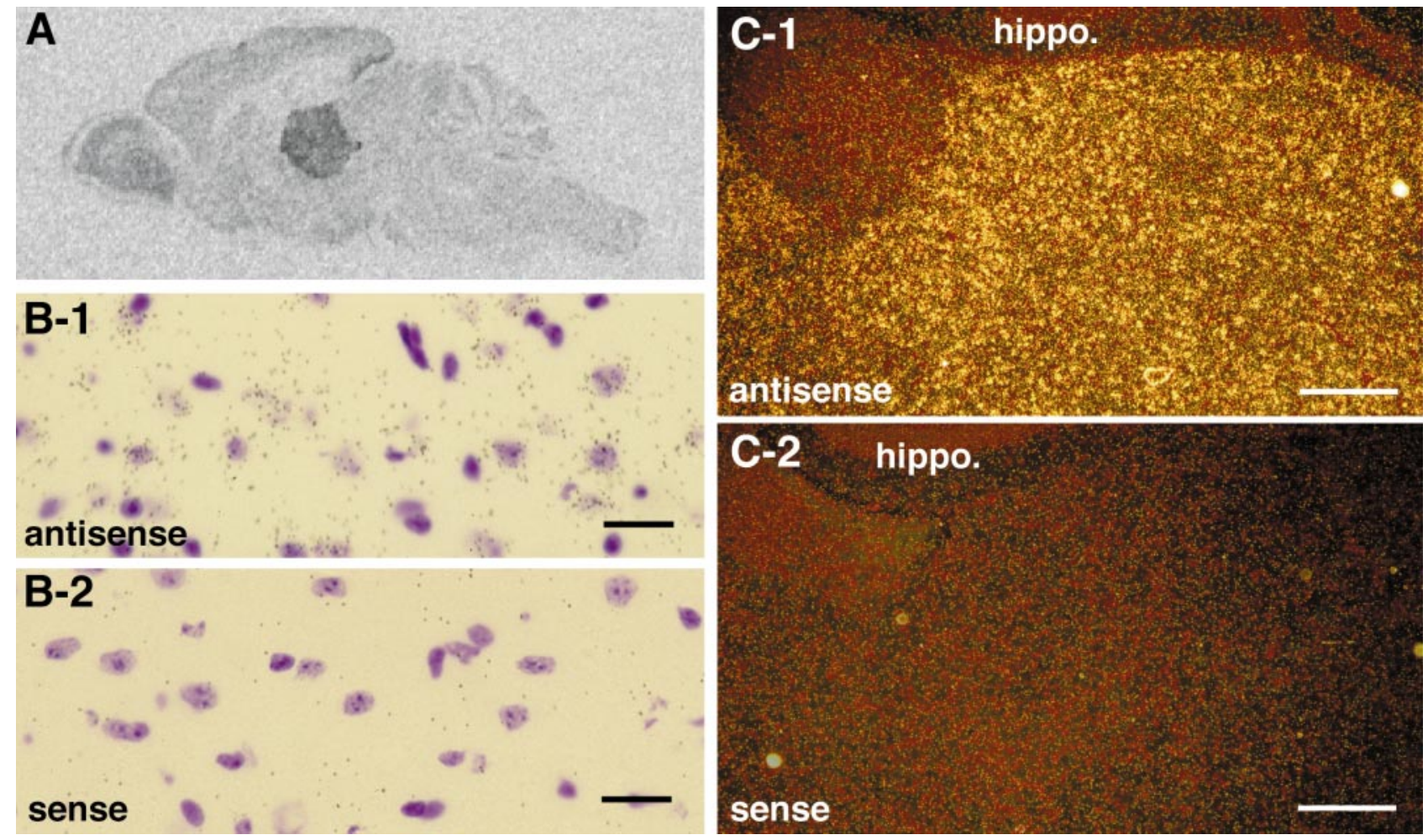

Figure 3. Citron is abundantly expressed in the thalamus. $A$, Film autoradiography of a parasagittal section of an adult mouse brain examined by in situ hybridization using an antisense riboprobe of Citron mRNA. $B-1, B-2$, Light-field views of individual thalamic neurons expressing Citron mRNA; most thalamic neurons were positive and associated with numerous silver grains. Scale bars, $20 \mu \mathrm{m} . C-1, C$-2, Dark-field view of Citron mRNA expression in the thalamus; note the sharp contrast between the high expression in the thalamus compared with the hippocampal formation (hippo.). Scale bars, $80 \mu \mathrm{m}$. In $B$ and $C$, adjacent sections hybridized using antisense and sense probes are shown.

plasmids were cotransfected and expressed into these $\mathrm{CHO}$ cells, NR1 and NR2A were induced by heat (Fig. 7B). Under these conditions, the Citron immune complex recovered a significant amount of NR2A-IR (Fig. 7B, lane 3). However, in the absence of PSD-95 expression, NR2A could not be pulled down (Fig. 7B, lane 2), indicating that PSD-95 is required to form a bridge between Citron and NMDA receptor.

\section{DISCUSSION}

\section{Direct interaction between Citron, a Rho-target, with PSD-95/SAP-90}

Recent findings indicate that PDZ domain-containing proteins, such as inaD or members of the MAGUK family (e.g., PSD-95/ SAP-90 and Dlg/SAP-97), may represent scaffold proteins whose role is to organize a subsynaptic lattice consisting of various key signaling molecules anchored to the PDZ domains via their respective PDZ-binding sequences (Hsueh et al., 1997; Tsunoda et al., 1997; Zito et al., 1997). The identification of the PDZbinding motifs in various synaptic proteins has given rise to a consensus tSXV motif, conserved across a large number of PDZtargets, including NR2 subunits of NMDA receptor and some of the $\alpha$ subunits of voltage-gated potassium and sodium channels (Sheng and Wyszynski, 1997). Recent cloning of several molecules with binding specificity toward the active GTP-bound form of Rho has enabled us to examine whether a member of the Rho-interacting proteins could participate in such postsynaptic microdomains of signaling molecules. Surprisingly, the first isolated Rho-binding protein in our department, Citron, had such a motif (Fig. 1A) (Madaule et al., 1995). We found that Citron is an abundant PSD protein in the brain, with a particularly high expression in the thalamus and cerebral cortex (Figs. $1 B, 2 A, 3 A$ ). Its function in the brain had remained elusive, but the multiplicity of protein-association motifs (coiled-coil domain, leucine zipper motif, $\mathrm{Zn}$-finger motif, $\mathrm{PH}$ domain, and $\mathrm{SH} 3$-binding proline-rich sequence) in Citron had suggested that Citron might act as an adapter protein involved in linking the Rho activity to another protein signaling complex (Madaule et al., 1995).

Our work confirmed the potential for the C-terminal end of Citron to directly associate with the PDZ domains in PSD-95/ SAP-90 (Fig. 6). Furthermore, the presence of Citron in the PSD-95 immunoprecipitates from the thalamic lysates indicated that the formation of a Citron-PSD-95 complex is possible in intact thalamic neurons (Fig. $1 E$ ). Immunocytochemical examination of Citron distribution using two different Citron antibodies revealed a primarily somatodendritic distribution of Citron-IR (Fig. 2B; data not shown), and in particular, a colocalization of Citron was observed in a significant number of PSD-95- and NR1-containing postsynaptic puncta but not in all (Fig. 2B). These immunocytochemical data were supported by the biochemical cofractionation of Citron, PSD-95, and NR1 proteins into the PSD fraction (Fig. $2 A$ ). Together, it is tempting to infer that Citron may play a role as a PSD-95/SAP-90-binding protein at certain, but not all, PSD loci. Similar conclusions were reached by another group (Zhang et al., 1999). At this point, it remains to be seen whether Citron, which is present in the PSD-95-negative puncta, may in fact be bound to other PSD-95/ SAP-90-related or PDZ-domain-containing proteins. 

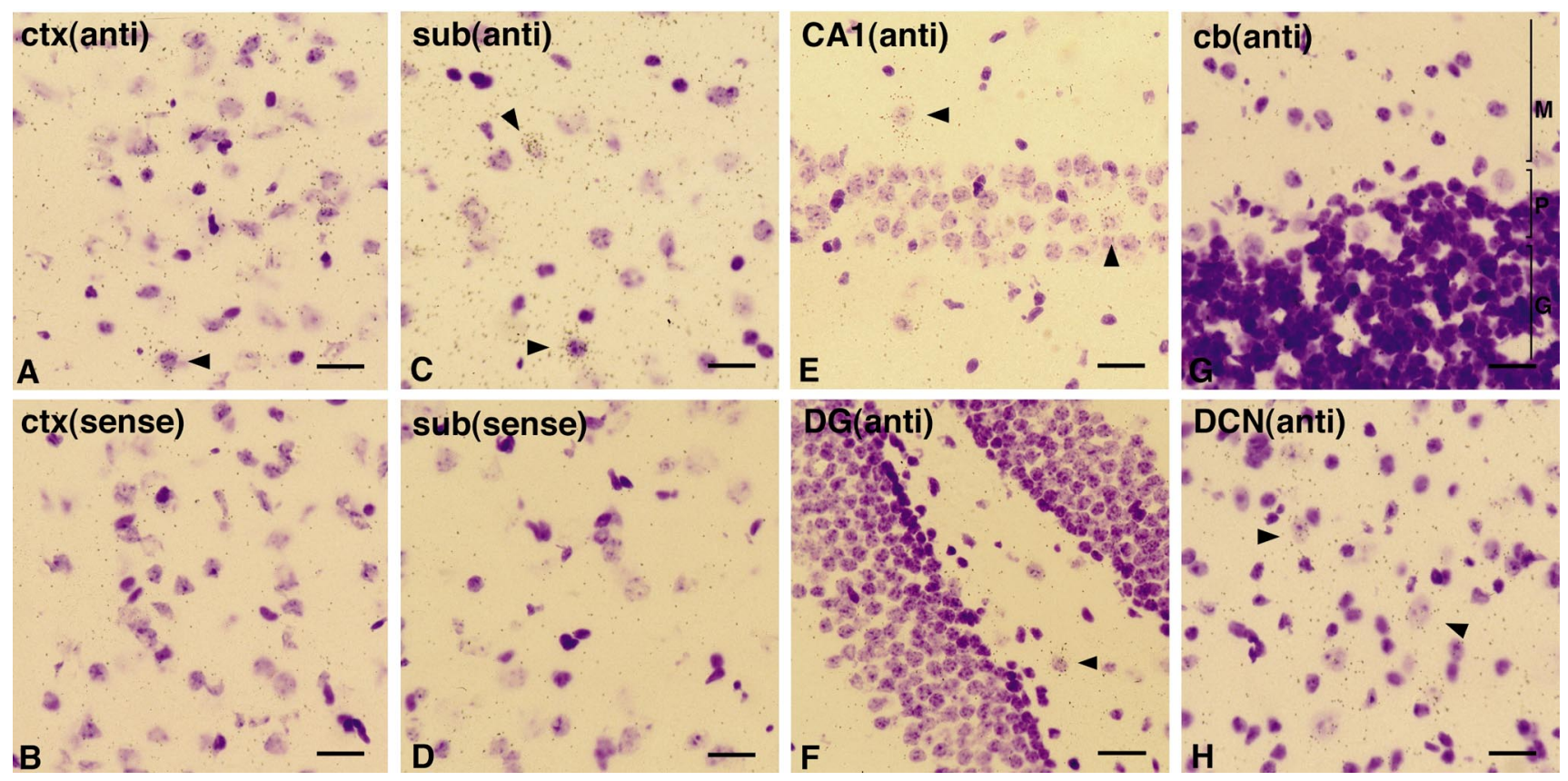

Figure 4. Restricted expression pattern of Citron mRNA in various brain areas. $A, B$, A moderate and diff use Citron mRNA expression was detected throughout the cerebral cortex (ctx). $C, D$, Similarly, a diff use expression was noted in the subiculum (sub) of the hippocampus. $E, F$, Absence of Citron mRNA in the pyramidal (CA1) and granule $(D G)$ neurons of the hippocampus; Citron mRNA-positive neurons were limited to scattered neurons throughout the hippocampus. $G$, Absence of Citron mRNA from the molecular $(M)$, Purkinje cell $(P)$, and granule cell $(G)$ layers of the cerebellum $(c b) . H$, A number of neurons in the deep cerebellar nuclei $(D C N)$ are heavily stained with silver grains. In $A, B$ and $C, D$, adjacent sections hybridized using antisense (anti) and sense probes are shown. Scale bars: $A-D, G, H, 20 \mu \mathrm{m} ; E, F, 26.7 \mu \mathrm{m}$.

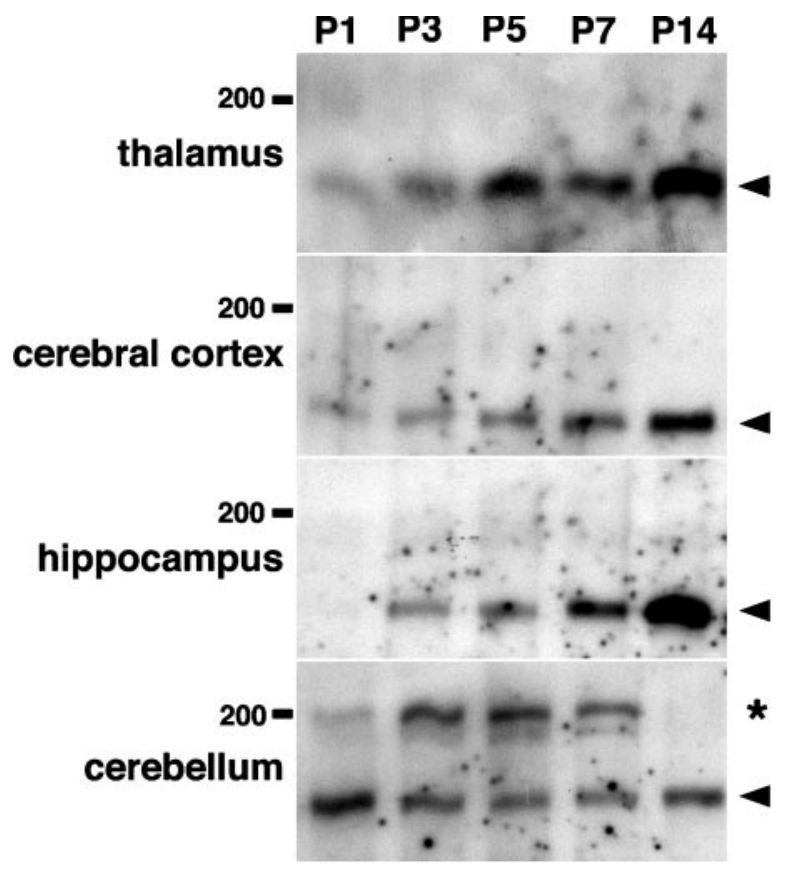

Figure 5. Developmentally regulated expression of Citron protein in various brain areas. The expression of Citron (arrowhead) is increased gradually from P1-P14 in the thalamus, the cerebral cortex, and the hippocampus. A larger Citron isoform (asterisk) is transiently induced in the cerebellum between P3 and P7. Five micrograms of proteins were loaded in each lane.

\section{Reconstitution of Citron-PSD-95-NMDA receptor complex in a heterologous system}

Short of currently being able to significantly modify the CitronPSD-95 interaction in situ without severely affecting the entire
Rho pathway or PSD-95/SAP-90 signaling complex, we reconstituted the Citron-PSD-95 complex in heterologous cell systems. The formation of a complex containing both Citron and PSD-95/ SAP-90 was confirmed by the fact that each one of the partners could coimmunoprecipitate each other to a large extent (up to $10 \%$ in some experiments) in COS-7 (Fig. 6) or CHO cells (data not shown). Furthermore, a redistribution of PSD-95 was detected in COS-7 cells when Citron was coexpressed; PSD-95 was not diffusely localized any more but now extensively colocalized with Citron (Fig. 6C). Thus, the localization signal in Citron was probably dominant over that in PSD-95. In an independent work (Madaule et al., 1998), Rho binding appeared to be important for appropriate Citron distribution within dividing cells; whether that observation is also valid in postmitotic neurons still remains to be tested.

In addition, we were able to demonstrate that NMDA receptor subunits, induced after overexpression of Citron and PSD-95, were competent to form a complex with Citron in a PSD-95dependent manner (Fig. 7B). Our methods (sequential inductioncoimmunoprecipitation), however, do not have the resolution to discriminate whether a single PSD-95/SAP-90 molecule provides a direct bridge between Citron and NR2A subunit or whether a multimer of PSD-95/SAP-90 resides between the two molecules. Nevertheless, a biochemical cofractionation into the PSD fraction and a physical colocalization at synaptic puncta in cultured neurons were demonstrated for Citron/PSD-95/NMDA receptors (Fig. 2), rendering it likely that the three components of this complex may be coexpressed in a close molecular vicinity in vivo.

\section{An area-specific and cell type-specific synaptic role for Citron?}

What may be the role for such an interaction between Citron and PSD-95? Citron mRNA was expressed to a variable degree in the 
A

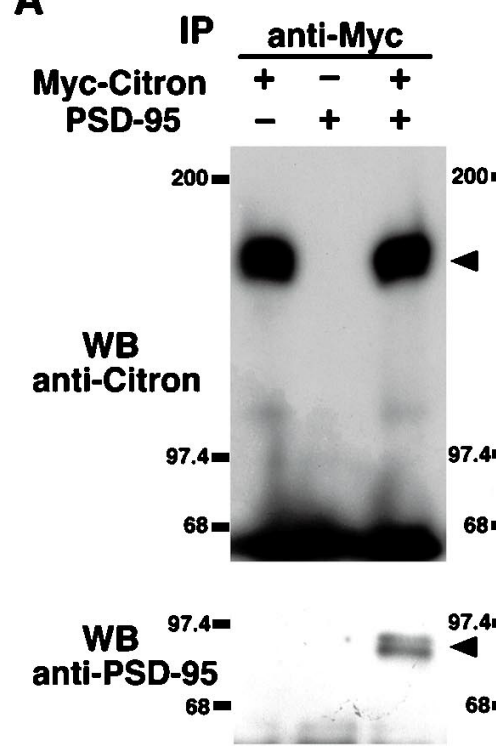

B
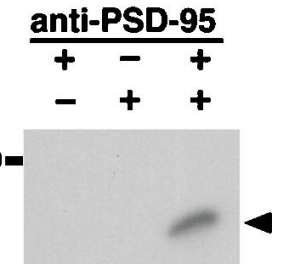

C(t/SXV-)

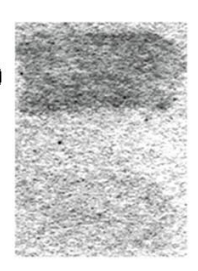

C

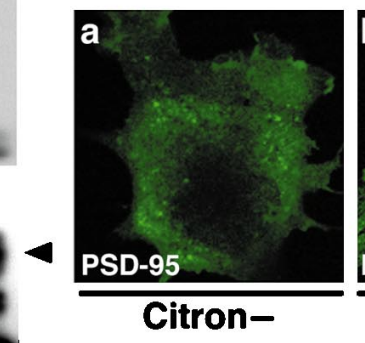

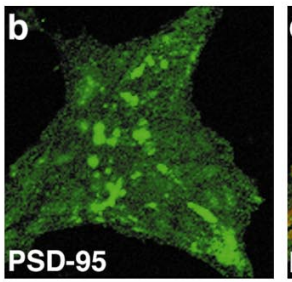

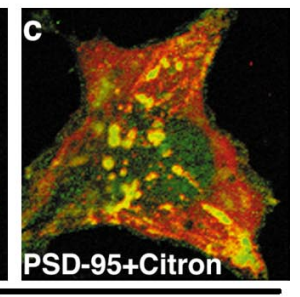

Citron+

Figure 6. Direct Citron-PSD-95 interaction in a heterologous system. $A$, Citron and PSD-95, when overexpressed in COS-7 cells, form a stable complex, thus enabling either one of the proteins to be immunoprecipitated with an antibody against the other. $B$, Direct binding of Citron to the PDZ motifs of PSD-95 requires an intact $\mathrm{C}$-terminal $\mathrm{tSXV}$ motif $[\mathrm{C}(\mathrm{t} / \mathrm{SXV}+)]$. $\mathrm{C}(\mathrm{t} / \mathrm{SXV}+)$ alone was sufficient to induce lacZ activity, whereas the deletion of the $\mathrm{C}$-terminal four amino acids $[\mathrm{C}(\mathrm{t} / \mathrm{SXV}-)]$ abolished it in a yeast two-hybrid assay. $C$, PSD-95 immunoreactivity is influenced by coexpression of Citron in COS-7 cells. PSD-95 expression is initially diff use $(a)$ in the absence of Citron expression. However, when Citron overexpressed, PSD-95 is primarily relocalized into an intracellular compartment $(b)$ that is enriched with Citron protein $(c)$. Each picture, $50 \mu \mathrm{m} \times 50 \mu \mathrm{m}$.

majority of excitatory neurons in the thalamus and cerebral cortex, in the inhibitory output from the striatum, probably in the inhibitory neurons of the hippocampus, and in some neurons belonging to the cerebellar deep nuclei, whereas it was clearly absent from the pyramidal and dentate granule neurons of the hippocampus, as well as from the Purkinje cells and granule cells of the cerebellum (Fig. 4; data not shown). Thus, the distribution of Citron and PSD-95/SAP-90 seems to primarily overlap in some brain areas, although it remains distinct in others. Interestingly, Citron expression was regulated developmentally, in close synchrony with the formation of synapses in various brain areas (Fig. 5). The gradual rise in expressed Citron protein was in parallel to the reported profile for PSD-95/SAP-90 (Cho et al., 1992; Kistner et al., 1993). The difference in spatial localization between Citron and PSD-95/SAP-90 stands in contrast with the similarity in their temporal expression. Such an apparent dichotomy would be most consistent with the idea of Citron acting as a region-specific and/or cell type-specific modifier of PSD-95/SAP-90 and related proteins. However, because the biological functions of PSD-95/ SAP-90 themselves are not fully understood yet, it would seem too early to speculate about the precise significance of its modifier. Further studies are needed to establish the contribution of Citron in the PSD-95-dependent regulation of the synaptic signaling complex.

A caveat in the current neuronal Rho signaling research lies in the relative paucity of data regarding the function and expression of Rho family members in the mature dendrites, although an abundant literature is already available for the role of Rho signaling in growth cone remodeling mediated via actin-based cytoskeletal rearrangement. In fact, actin cytoskeleton is concentrated not only at the leading edge of an extending growth cone but also in the PSD of dendritic spines (Allison et al., 1998). Recently, an overexpression of a GTPase-deficient Rac1 mutant in Purkinje neurons in transgenic mice was associated with severe morphological alteration in the dendritic arbor (Luo et al., 1996), without affecting the generation of long-term depression at these synapses (Hensch et al., 1997). Transfections of mutant Rho, Rac, and $\mathrm{CDC} 42$ have also been shown to alter the number of the dendrites and the shape of the soma in cultured cortical neurons (Threadgill et al., 1997). Such dendritic remodeling, in principle, may participate during many phases of structural modifications of the neurons, which occur during the early development or in an activity-dependent manner after the synaptic connections have been established. However, there is still little evidence that allows us to consider whether the molecular cycling between the GTPand GDP-bound states has implications that goes beyond cytoskeletal and morphological changes. The finding of a molecular association between Citron and PSD-95/SAP-90 may provide a helpful hint to unravel such additional significance of the Rho signaling, especially in the adult brain.

In conclusion, our study demonstrates a molecular association between a Rho-effector molecule, Citron, with a postsynaptic scaffold protein, PSD-95/SAP-90, a candidate anchor for multiple signaling components in the postsynaptic density. The coexistence of both a Rho-target and the NMDA receptor subunits in such a specialized complex of signaling cascades makes it likely to envisage a potential cross talk between these two pathways, both essential in several aspects of neural plasticity. Proximity increases the chance of coincident activation and usually generates a qualitative change in the efficiency of signal coupling, selectivity of activated pathways, and speed of signal propagation. The presence of a Rho effector in the synaptic receptor-channel complex may be a clue to further elucidate certain types of activity-dependent coordination and modification of dendritic properties. The precise nature of the cross talk between the Rho signaling system and the NMDA receptor-mediated signaling will have to await future in depth studies. 
A

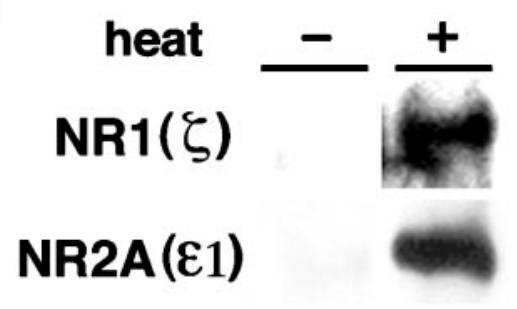

B

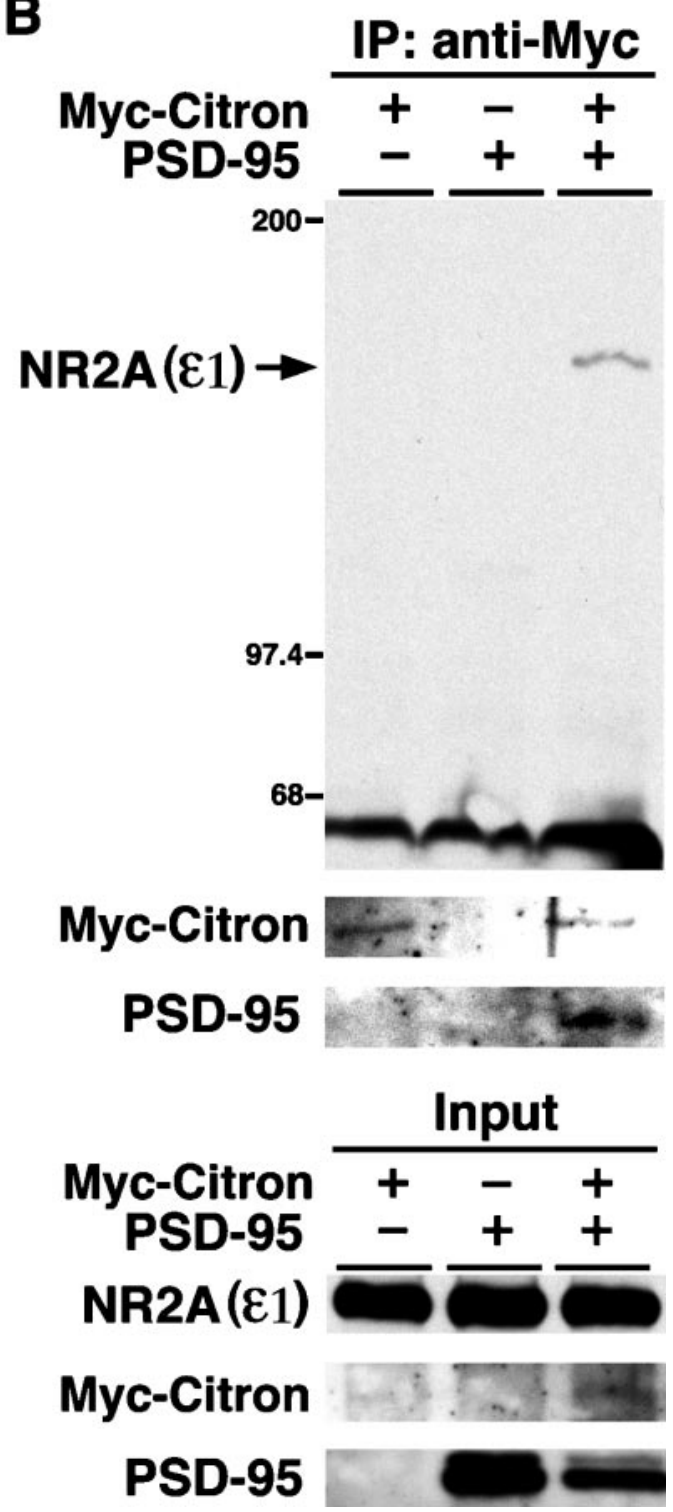

Figure 7. Formation of a Citron-PSD-95-NMDA receptor complex in vitro. $A$, Heat-induced expression of NR1 $(\zeta)$ and NR2A $(\epsilon 1)$ subunits in heat-inducible $\mathrm{CHO}$ stable transfectants. $B$, Immune complex formation between Myc-Citron, PSD-95, and NMDA receptor subunits. Coexpression of PSD-95 is necessary for the recovery of NR2A subunit into the immunoprecipitate $(I P)$ obtained using an anti-Myc antibody. Note that heat-induced expression level of the NR2A subunit in the input is not altered by a previous coexpression of Myc-Citron and PSD- 95 by transient transfection.

\section{REFERENCES}

Allen KM, Gleeson JG, Bagrodia S, Partington MW, MacMillan JC, Cerione RA, Mulley JC, Walsh CA (1998) PAK3 mutation in nonsyndromic X-linked mental retardation. Nat Genet 20:25-30.

Allison DW, Gelfand VI, Spector I, Craig AM (1998) Role of actin in anchoring postsynaptic receptors in cultured hippocampal neurons: differential attachment of NMDA versus AMPA receptors. J Neurosci 18:2423-2436.

Billuart P, Bienvenu T, Ronce N, des Portes V, Vinet MC, Zemni R, Crollius HG, Carrie A, Fauchereau F, Cherry M, Briault S, Hamel B, Fryns J-P, Beldjord C, Kahn A, Moraine C, Chelly J (1998) Oligophrenin-1 encodes a rhoGAP protein involved in X-linked mental retardation. Nature 392:923-926.

Bito H, Deisseroth K, Tsien RW (1996) CREB phosphorylation and dephosphorylation: a $\mathrm{Ca}^{2+}$ - and stimulus duration-dependent switch for hippocampal gene expression. Cell 87:1203-1214.

Brenman JE, Chao DS, Gee SH, McGee AW, Craven SE, Santillano DR, Wu Z, Huang F, Xia H, Peters MF, Froehner SC, Bredt DS (1996) Interaction of nitric oxide synthase with the postsynaptic density protein PSD-95 and alpha1-syntrophin mediated by PDZ domains. Cell 84:757-767.

Carlin RK, Grab DJ, Cohen RS, Siekevitz P (1980) Isolation and characterization of postsynaptic densities from various brain regions: enrichment of different types of postsynaptic densities. J Cell Biol 86:831-845.

Chen W, Lim L (1994) The Caenorhabditis elegans small GTP-binding protein RhoA is enriched in the nerve ring and sensory neurons during larval development. J Biol Chem 269:32394-32404.

Cho KO, Hunt CA, Kennedy MB (1992) The rat brain postsynaptic density fraction contains a homolog of the Drosophila discs-large tumor suppressor protein. Neuron 9:929-942.

Cohen NA, Brenman JE, Snyder SH, Bredt DS (1996) Binding of the inward rectifier $\mathrm{K}^{+}$channel Kir 2.3 to PSD-95 is regulated by protein kinase A phosphorylation. Neuron 17:759-767.

Erondu NE, Kennedy MB (1985) Regional distribution of type II Ca ${ }^{2+} /$ calmodulin-dependent protein kinase in rat brain. J Neurosci 5:3270-3277.

Fujisawa K, Madaule P, Ishizaki T, Watanabe G, Bito H, Saito Y, Hall A, Narumiya S (1998) Different regions of Rho determine Rho-selective binding of classes of Rho target molecules. J Biol Chem 273:18943-18949.

Gebbink MF, Kranenburg O, Poland M, van Horck FP, Houssa B, Moolenaar WH (1997) Identification of a novel putative Rho-specific GDP/GTP exchange factor and a RhoA-binding protein: control of neuronal morphology. J Cell Biol 137:1603-1613.

Gomperts SN (1996) Clustering membrane proteins: it's all coming together with the PSD-95/SAP-90 protein family. Cell 84:659-662.

Hall A (1998) Rho GTPases and the actin cytoskeleton. Science 279:509-514.

Hensch TK, Luo L, Jan LY, Jan YN (1997) Synaptic plasticity at miniaturized spines on Purkinje cells expressing constitutively active Rac GTPase. Soc Neurosci Abstr 23:448.8.

Hirose M, Ishizaki T, Watanabe N, Uehata M, Kranenburg O, Moolenaar WH, Matsumura F, Maekawa M, Bito H, Narumiya S (1998) Molecular dissection of the Rho-associated protein kinase (p160ROCK)regulated neurite remodeling in neuroblastoma N1E-115 cells. J Cell Biol 141:1625-1636.

Horio Y, Hibino H, Inanobe A, Yamada M, Ishii M, Tada Y, Satoh E, Hata Y, Takai Y, Kurachi Y (1997) Clustering and enhanced activity of an inwardly rectifying potassium channel Kir4.1 by an anchoring protein PSD-95/SAP90. J Biol Chem 272:12885-12888.

Hsueh YP, Kim E, Sheng M (1997) Disulfide-linked head-to-head multimerization in the mechanism of ion channel clustering by PSD-95. Neuron 18:803-814.

Irie M, Hata Y, Takeuchi M, Ichtchenko K, Toyoda A, Hirao K, Takai Y, Rosahl TW, Sudhof TC (1997) Binding of neuroligins to PSD-95. Science 277:1511-1515.

Ishizaki T, Naito M, Fujisawa K, Maekawa M, Watanabe N, Saito Y, Narumiya S (1997) p160ROCK, a Rho-associated coiled-coil forming protein kinase, works downstream of Rho and induces focal adhesions. FEBS Lett 404:118-124.

Jalink K, van Corven EJ, Hengeveld T, Morii N, Narumiya S, Moolenaar WH (1994) Inhibition of lysophosphatidate- and thrombin-induced neurite retraction and neuronal cell rounding by ADP ribosylation of the small GTP-binding protein Rho. J Cell Biol 126:801-810. 
Jin Z, Strittmatter SM (1997) Rac1 mediates collapsin-1-induced growth cone collapse. J Neurosci 17:6256-6263.

Kennedy MB (1997) The postsynaptic density at glutamatergic synapses. Trends Neurosci 20:264-268.

Kim E, Niethammer M, Rothschild A, Jan YN, Sheng M (1995) Clustering of Shaker-type $\mathrm{K}^{+}$channels by interaction with a family of membrane-associated guanylate kinases. Nature 378:85-88.

Kim E, Cho KO, Rothschild A, Sheng M (1996) Heteromultimerization and NMDA receptor-clustering activity of Chapsyn-110, a member of the PSD-95 family of proteins. Neuron 17:103-113.

Kistner U, Wenzel BM, Veh RW, Cases-Langhoff C, Garner AM, Appeltauer U, Voss B, Gundelfinger ED, Garner CC (1993) SAP90, a rat presynaptic protein, related to the product of the Drosophila tumor suppressor gene dlg-A. J Biol Chem 268:4580-4583.

Kornau HC, Schenker LT, Kennedy MB, Seeburg PH (1995) Domain interaction between NMDA receptor subunits and the postsynaptic density protein PSD-95. Science 269:1737-1740.

Kozma R, Sarner S, Ahmed S, Lim L (1997) Rho family GTPases and neuronal growth cone remodelling: relationship between increased complexity induced by $\mathrm{Cdc} 42 \mathrm{Hs}$, Rac1 and acetylcholine, and collapse induced by RhoA and lysophosphatidic acid. Mol Cell Biol 17:1201-1211.

Lahey T, Gorczyca M, Jia XX, Budnik V (1994) The Drosophila tumor suppressor gene dlg is required for normal synaptic bouton structure Neuron 13:823-835.

Lau LF, Mammen A, Ehlers MD, Kindler S, Chung WJ, Garner CC, Huganir RL (1996) Interaction of the $N$-methyl-D-aspartate receptor complex with a novel synapse-associated protein SAP102. J Biol Chem 271:21622-21628.

Lim L, Manser E, Leung T, Hall C (1996) Regulation of phosphorylation pathways by p21 GTPases. The p21 Ras-related Rho subfamily and its role in phosphorylation signalling pathways. Eur $\mathrm{J}$ Biochem 242:171-185.

Luo L, Liao YJ, Jan LY, Jan YN (1994) Distinct morphogenetic functions of similar small GTPases: Drosophila Drac1 is involved in axonal outgrowth and myoblast fusion. Genes Dev 8:1787-1802.

Luo L, Hensch TK, Ackerman L, Barbel S, Jan LY, Jan YN (1996) Differential effects of the Rac GTPase on Purkinje cell axons and dendritic trunks and spines. Nature 379:837-840.

Mackay DJ, Nobes CD, Hall A (1995) The Rho's progress: a potential role during neuritogenesis for the Rho family of GTPases. Trends Neurosci 18:496-501.

Madaule P, Axel R (1985) A novel ras-related gene family. Cell 41:31-40.

Madaule P, Furuyashiki T, Reid T, Ishizaki T, Watanabe G, Morii N, Narumiya S (1995) A novel partner for the GTP-bound forms of rho and rac. FEBS Lett 377:243-248.

Madaule P, Eda M, Watanabe N, Fujisawa K, Matsuoka T, Bito H, Ishizaki T, Narumiya S (1998) Role of Citron kinase as a target of the small GTPase Rho in cytokinesis. Nature 394:491-494.

Malosio ML, Gilardelli D, Paris S, Albertinazzi C, de Curtis I (1997) Differential expression of distinct members of Rho family GTP-binding proteins during neuronal development: identification of Rac1B a new neural-specific member of the family. J Neurosci 17:6717-6728.

Narumiya S (1996) The small GTPase Rho: cellular functions and signal transduction. J Biochem (Tokyo) 120:215-228.

Narumiya S, Ishizaki T, Watanabe N (1997) Rho effectors and reorganization of actin cytoskeleton. FEBS Lett 410:68-72.

Nishiki T, Narumiya S, Morii N, Yamamoto M, Fujiwara M, Kamata Y,
Sakaguchi G, Kozaki S (1990) ADP-ribosylation of the rho/rac proteins induces growth inhibition, neurite outgrowth and acetylcholine esterase in cultured PC-12 cells. Biochem Biophys Res Commun 167:265-272.

Nobes CD, Hall A (1995) Rho, rac, and cdc42 GTPases regulate the assembly of multimolecular focal complexes associated with actin stress fibers lamellipodia and filopodia. Cell 81:53-62.

Oida H, Namba T, Sugimoto Y, Ushikubi F, Ohishi H, Ichikawa A, Narumiya S (1995) In situ hybridization studies of prostacyclin receptor mRNA expression in various mouse organs. $\mathrm{Br} \mathrm{J}$ Pharmacol 116:2828-2837.

Olenik C, Barth H, Just I, Aktories K, Meyer DK (1997) Gene expression of the small GTP-binding proteins RhoA, RhoB, Rac1 and Cde42 in adult rat brain. Brain Res Mol Brain Res 52:263-269.

Sasamura T, Kobayashi T, Kojima S, Qadota H, Ohya Y, Masai I, Hotta Y (1997) Molecular cloning and characterization of Drosophila genes encoding small GTPases of the rab and rho families. Mol Gen Genet 254:486-494.

Sheng M, Wyszynski M (1997) Ion channel targeting in neurons. BioEssays 19:847-853.

Songyang Z, Fanning AS, Fu C, Xu J, Marfatia SM, Chishti AH, Crompton A, Chan AC, Anderson JM, Cantley LC (1997) Recognition of unique carboxyl-terminal motifs by distinct PDZ domains. Science 275:73-77.

Steven R, Kubiseski TJ, Zheng H, Kulkarni S, Mancillas J, Ruiz Morales A, Hogue CW, Pawson T, Culotti J (1998) UNC-73 activates the Rac GTPase and is required for cell and growth cone migrations in $C$. elegans. Cell 92:785-795.

Threadgill R, Bobb K, Ghosh A (1997) Regulation of dendritic growth and remodeling by Rho, Rac and Cdc42. Neuron 19:625-634.

Tigyi G, Fischer DJ, Sebok A, Yang C, Dyer DL, Miledi R (1996) Lysophosphatidic acid-induced neurite retraction in PC12 cells: control by phosphoinositide- $\mathrm{Ca}^{2+}$ signaling and Rho. J Neurochem 66:537-548.

Tsunoda S, Sierralta J, Sun Y, Bodner R, Suzuki E, Becker A, Socolich M, Zuker CS (1997) A multivalent PDZ-domain protein assembles signalling complexes in a G-protein-coupled cascade. Nature 388:243-249.

Uchino S, Kudo Y, Watanabe W, Nakajima-Iijima S, Mishina M (1997) Inducible expression of $N$-methyl-D-aspartate (NMDA) receptor channels from cloned cDNAs in CHO cells. Brain Res Mol Brain Res 44:1-11.

Wendland B, Schweizer FE, Ryan TA, Nakane M, Murad F, Scheller RH, Tsien RW (1994) Existence of nitric oxide synthase in rat hippocampal pyramidal cells. Proc Natl Acad Sci USA 91:2151-2155.

Woods DF, Bryant PJ (1993) ZO-1 DlgA and PSD-95/SAP90: homologous proteins in tight septate and synaptic cell junctions. Mech Dev 44:85-89.

Zhang W, Vazquez L, Apperson M, Kennedy MB (1999) Citron binds to PSD-95 at glutamatergic synapses on inhibitory neurons in the hippocampus. J Neurosci 19:96-108.

Ziff EB (1997) Enlightening the postsynaptic density. Neuron 19:1163-1174.

Zipkin ID, Kindt RM, Kenyon CJ (1997) Role of a new Rho family member in cell migration and axon guidance in C. elegans. Cell 90:883-894.

Zito K, Fetter RD, Goodman CS, Isacoff EY (1997) Synaptic clustering of Fascilin II and Shaker: essential targeting sequences and role of Dlg. Neuron 19:1007-1016. 